\title{
PENGARUH PERBANDINGAN BAHAN DENGAN PELARUT ASETON TERHADAP TOTAL FENOLIK, WARNA DAN KLOROFIL EKSTRAK Sargassum polycystum
}

\author{
I Putu Fajardhiputra Hernes ${ }^{1}$, Lutfi Suhendra ${ }^{2}$, Luh Putu Wrasiati ${ }^{2}$ \\ ${ }^{1}$ Mahasiswa Jurusan Teknologi Industri Pertanian, Fakultas Teknologi Pertanian, Unud \\ ${ }^{2}$ Dosen Jurusan Teknologi Industri Pertanian, Fakultas Teknologi Pertanian, Unud \\ Kampus Bukit Jimbaran, Badung-Bali \\ E-mail: fajardhiputra@gmail.com ${ }^{1}$ \\ E-mail koresponden: lutfi_s@unud.ac.id ${ }^{2}$
}

\begin{abstract}
Seaweed is one of the biological resources that its existence is very abundant in all marine waters in Indonesia. One of them is Sargassum polycystum which is a type of brown algae (Phaeophyceae). The purpose of this study was to determine the effect of comparison the material with the solvent to the color content, the total phenolic and chlorophyll of Sargassum polycystum extract, and to determine the comparative treatment of the material with best solvent to produce Sargassum polycystum extract. This experiment uses a simple Group Randomized Design (GRD) consisting 5 comparisons of materials with the acetone (w/v) ie (1:9), (1:11), (1:13), (1:15), (1:17). Furthermore, the treatment is repeated as much as 3 times based on implementation time, to obtained 15 units of experiments. The results showed the ratio of material with the solvent had a very significant effect $(\mathrm{P}<0.01)$ on the rendement parameters, brightness $\left(\mathrm{L}^{*}\right)$, redness $\left(\mathrm{a}^{*}\right)$, yellowishness $(\mathrm{b} *)$, total phenolic, chlorophyll a and total chlorophyll. The results had significant effect $(\mathrm{P}<0.05)$ shown on chlorophyll $b$ parameters. The best treatment was obtained from the treatment with the highest value on several parameters tested ie, yield, total phenolic and chlorophyll content. Comparison of material with acetone solvent (1:15) (w/v) was the best treatment with yield of $2.27 \%$, color intensity ( $\left.\mathrm{L}^{*}\right)$ 5.08, (a*) -5.62, (b*) 54.00, total phenolic $0.95 \mathrm{mgGAE} / 100 \mathrm{~g}$, chlorophyll a 279 ppm, chlorophyll b 134 ppm and total chlorophyll 310 ppm.
\end{abstract}

Key words: Sargassum polycystum, compounds bioactive, comparison of material with solvent.

\section{PENDAHULUAN}

Sargassum polycystum merupakan kelas alga coklat (Phaeophyceae) yang tumbuh dan tersebar hampir di seluruh perairan laut di Indonesia. Sargassum polycystum yang banyak ditemukan di Pantai Sanur belum ada pembudidayaan secara optimal serta masyarakat belum banyak tahu potensi yang dihasilkan. Dari penelitian yang telah dilakukan, rumput laut jenis ini diketahui memiliki kandungan kimia dan warna yang dapat dimanfaatkan. Salah satu kandungan yang dapat ditemukan dalam Sargassum polycystum adalah alginat (Atmadja et al., 1996).

Sargassum polycystum juga mengandung beberapa pigmen diantaranya adalah fukosantin, klorofil, karoten dan mungkin masih terdapat jenis pigmen lainnya. Namun, fukosantin sangat dominan memberikan warna coklat tua hingga kuning coklat pada hasil celupan (Eriningsih et al., 2014). Pigmen dari rumput laut coklat terutama fukosantin memiliki banyak manfaat dibidang kesehatan yaitu sebagai antioksidan, antikanker, anti peradangan, dan anti obesitas (Maeda, et al., 2005 \&2007; Nomura, et al., 1997; Nara et al., 2005 dan Panovska et al., 2005).

Penggunaan klorofil bagi tubuh manusia yaitu dapat membantu dalam meningkatkan jumlah sel-sel darah, khususnya meningkatkan produksi hemoglobin dalam darah, membersihkan jaringan 
tubuh, meningkatkan daya tahan tubuh, terhadap senyawa asing (virus, bakteri, parasit), melindungi DNA terhadap kerusakan. Penelitian dari Wignore (1985) menyatakan bahwa klorofil dapat melindungi kita dari senyawa-senyawa karsinogen, apabila makanan dan obat lainnya sudah tidak berfungsi lagi.

Fenol meliputi senyawa yang berasal dari tumbuhan dan mempunyai ciri yang sama, yaitu cincin aromatik yang mengandung satu atau dua gugus hidroksil. Flavonoid merupakan golongan fenol terbesar. Senyawa fenol merupakan senyawa yang dapat larut dalam senyawa polar dan sedikit polar (Chismirina et. al., 2010). Dari hasil penelitian Baihakki et al. (2014) tentang ekstraksi senyawa polifenol dari Sargassum sp. menghasilkan senyawa polifenol tertinggi pada jenis rumput laut Sargassum polycystum.

Ektraksi menggunakan pelarut untuk mendapatkan senyawa-senyawa bioaktif dan senyawa pigmen dipengaruhi oleh suhu, waktu, konsentrasi pelarut, jenis pelarut (kepolaran pelarut, ukuran bahan dan perbandingan bahan pelarut. Penelitian Dewi et al. (2016) tentang pengaruh konsentrasi pelarut etanol dan suhu maserasi terhadap rendemen dan kadar klorofil produk enkapsulasi ekstrak selada laut menunjukkan bahwa pada konsentrasi etanol 90\% menghasilkan karakteristik produk enkapsulasi bubuk selada laut terbaik dengan kadar total klorofil yaitu sebesar 306,28 ppm.

Perbandingan bahan dan pelarut merupakan salah satu faktor yang mempengaruhi proses ekstraksi zat bioaktif dalam suatu bahan. Dari penelitian Nasser (2011) variasi rasio pelarut etanol 96\% terhadap oleoresin temulawak menghasilkan total fenolik tertinggi pada variasi rasio 1:7 dalam tiga rasio yaitu 1:3, 1:5, dan 1:7. Berdasarkan penelitian Yudharini et al. (2016) buah pandan diekstrak menggunakan klorofom dengan perbandingan bahan dengan pelarut (1:11) merupakan perlakuan terbaik untuk menghasilkan ekstrak buah pandan dengan rendemen 2,60\%. Selain itu, berdasarkan penelitian Diantika et al. (2014) tentang pengaruh lama ekstraksi dan konsentrasi pelarut etanol terhadap ekstraksi antioksidan biji kakao menyatakan bahwa lama ekstraksi 20 jam menghasilkan nilai aktivitas antioksidan terbesar.

Berdasarkan hal tersebut perlu dilakukan penelitian mengenai pengaruh perbandingan pelarut dengan bahan terhadap warna, total fenolik dan klorofil ekstrak Sargassum polycystum. Tujuan dari penelitian ini adalah untuk mengetahui pengaruh perbandingan bahan dengan pelarut terhadap warna, total fenolik dan klorofil, serta menentukan perbandingan bahan dengan pelarut terbaik untuk menghasilkan warna, total fenolik dan klorofil ekstrak Sargassum polycystum.

\section{METODE PENELITIAN}

\section{Tempat dan Waktu}

Penelitian ini dilakukan di Laboratorium Rekayasa Proses dan Pengendalian Mutu, serta Laboratorium Analisis Pangan, Fakultas Teknologi Pertanian, Universitas Udayana. Waktu pelaksanaan mulai dari Agustus sampai Oktober 2017. 


\section{Bahan dan Alat}

Bahan yang digunakan dalam penelitian ini terdiri dari bahan baku dan bahan kimia. Bahan baku yang digunakan adalah rumput laut coklat jenis Sargassum polycystum yang diperoleh pada bulan Maret dari Pantai Sanur-Bali ( $8^{\circ} 68^{\prime} 42^{\prime \prime} \mathrm{S}$ dan $\left.115^{\circ} 26^{\prime} 44^{\prime \prime} \mathrm{E}\right)$. Bahan yang digunakan yaitu rumput laut coklat jenis Sargassum polycystum yang telah mengalami proses pengeringan dan telah diayak dengan ayakan 40 mesh. Bahan kimia yang digunakan yaitu, pelarut untuk ekstraksi yaitu aseton 90\% (Brataco). Sedangkan bahan kimia yang sifatnya pro analysis (pa) adalah akuades, asam galat/Gallic acid monohydrate (Sigma aldrich), aseton 80\%, metanol 99,9\% (Merck), Follin-ciaccalteu phenol (Merck), $\mathrm{Na}_{2} \mathrm{CO}_{3}$ (Merck).

Peralatan yang digunakan dalam penelitian ini adalah rotary evaporator vacum (Janke \& Kunkel RV 06 - ML), Color reader (Accuprob HH06) timbangan analitik (Shimadzu), Spektrofotometer (Genesys 10S UV-VIS), vortex (Barnstead Thermolyne Maxi Mix II), pipet mikro (Transferpette), Tip $100 \mu$ l, Tip $1000 \mu$ l.

\section{Rancangan Percobaan}

Percobaan ini menggunakan Rancangan Acak Kelompok (RAK) sederhana dan perlakuan perbandingan bahan dengan jenis pelarut aseton. Perbandingan bahan dengan jenis pelarut aseton terdiri dari 5 perlakuan yaitu, $\mathrm{P} 1=$ perbandingan bahan dengan pelarut aseton ialah $1: 9(\mathrm{~b} / \mathrm{v}), \quad \mathrm{P} 2=$ perbandingan bahan dengan pelarut aseton ialah $1: 11(\mathrm{~b} / \mathrm{v}), \mathrm{P} 3=$ perbandingan bahan dengan pelarut aseton ialah $1: 13(\mathrm{~b} / \mathrm{v}), \mathrm{P} 4=$ perbandingan bahan dengan pelarut aseton ialah $1: 15(\mathrm{~b} / \mathrm{v}), \mathrm{P} 5=$ perbandingan bahan dengan pelarut aseton ialah $1: 17(\mathrm{~b} / \mathrm{v})$.

Selanjutnya perlakuan tersebut diulang sebanyak 3 kali sehingga diperoleh 15 unit percobaan. Data yang diperoleh kemudian dianalisis dengan analisis variansi dan dilanjutkan menggunakan metode BNT (Beda Nyata Terkecil). Penentuan perlakuan terbaik dilihat berdasarkan nilai tertinggi dari beberapa parameter yang diuji yaitu rendemen, total fenolik dan kadar klorofil.

\section{Pelaksanaan Penelitian}

\section{Pembuatan Bubuk Sargassum polycystum}

Rumput laut Sargassum polycystum segar yang diperoleh dari Pantai Sanur dicuci dengan air laut kemudian dicuci bersih kembali dengan air tawar untuk menghilangkan sisa kotoran dan benda asing yang menempel. Rumput laut Sargassum polycystum ditempatkan pada nampan untuk ditiriskan dan kemudian dikeringkan dengan cara kering angin hingga mencapai kadar air $15 \pm 1 \%$ (Masduqi et al., 2014). Rumput laut Sargassum polycystum yang telah kering selanjutnya dihancurkan dan diayak menggunakan ayakan 40 mesh. 


\section{Pembuatan Ekstrak Sargassum polycystum}

Rumput laut Sargassum polycystum yang telah kering kemudian dihancurkan. Selanjutnya Sargassum ditimbang seberat 25 gram kemudian ditambahkan pelarut aseton teknis sebanyak $225 \mathrm{ml}$, $275 \mathrm{ml}, 325 \mathrm{ml}, 375 \mathrm{ml}, 425 \mathrm{ml}$ sesuai perlakuan. Campuran tersebut dikocok secara manual setiap 6 jam sekali selama 10 menit untuk mencapai kondisi homogen. Proses ekstraksi dengan metode maserasi dilakukan selama 24 jam pada suhu kamar $\pm 28^{\circ} \mathrm{C}$. Selanjutnya ekstrak disaring menggunakan kertas saring yang menghasilkan filtrat I dan ampas. Ampas ditambahkan pelarut sebanyak $50 \mathrm{ml}$, kemudian disaring dengan kertas saring sehingga menghasilkan Filtrat II (Antari, 2015). Filtrat I dan II dicampur dan disaring dengan kertas saring Whatman No. 1. Filtrat selanjutnya dievaporasi dengan rotary evaporator pada suhu $45^{\circ} \mathrm{C}$ dengan tekanan $100 \mathrm{mBar}$ untuk menghilangkan pelarut yang terdapat dalam ekstrak sampai semua pelarut habis menguap yang ditandai dengan pelarut tidak menetes lagi (Yudharini, 2016). Ekstrak kental yang diperoleh dimasukkan ke dalam botol sampel.

\section{Parameter yang Diamati}

Parameter yang diamati pada ekstrak Sargassum polycystum yaitu rendemen ekstrak (Sudarmadji et al., 1989), intensitas warna (Sistem L,a,b dalam Weaver, 1996 dan visual), total fenolik (Sakanaka et al., 2005), kadar klorofil (Nollet, 2004).

\section{HASIL DAN PEMBAHASAN}

\section{Rendemen Ekstrak}

Hasil analisis keragaman menunjukkan bahwa perlakuan perbandingan bahan dengan pelarut aseton berpengaruh sangat nyata $(\mathrm{P}<0,01)$ terhadap rendemen ekstrak Sargassum polycystum. Grafik nilai rata-rata rendemen dari ekstrak Sargassum polycystum dapat dilihat pada Gambar 1.

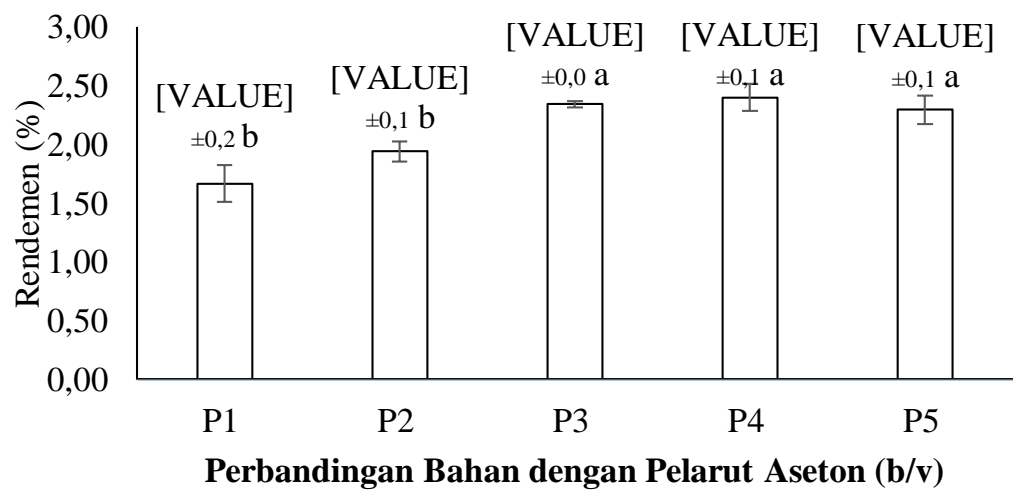

Keterangan:

$\mathrm{P} 1=$ bahan $:$ aseton $=(1: 9)$

$\mathrm{P} 2=$ bahan $:$ aseton $=(1: 11)$

$\mathrm{P} 3=$ bahan $:$ aseton $=(1: 13)$

$\mathrm{P} 4=$ bahan $:$ aseton $=(1: 15)$

$\mathrm{P} 5=$ bahan $:$ aseton $=(1: 17)$

Keterangan: Huruf yang berada di belakang angka menunjukan perbedaan yang sangat nyata $(\mathrm{P}<0,01)$. Data merupukan rata-rata dari tiga ulangan.

Gambar 1. Grafik nilai rata-rata rendemen ekstrak Sargassum polycystum (\%).

Analisis ini menunjukan bahwa pada perlakuan perbandingan bahan dengan pelarut aseton (b/v) P4 (1:15) menghasilkan rendemen ekstrak Sargassum polycystum yang tertinggi, yaitu 2,40\% dan berpengaruh sangat nyata terhadap perlakuan lainnya. Sedangkan perlakuan P1 (1:9) menghasilkan rendemen ekstrak Sargassum polycystum terendah, yaitu 1,67\%. 
Hal ini diduga terjadi karena pelarut yang digunakan sudah mencapai titik jenuh dan ini menyebabkan kadar rendemen yang dihasilkan tidak mengalami kenaikan lagi pada perlakuan (1:17) . Hasil penelitian Yudharini et al. (2016) yang meneliti tentang ekstraksi buah pandan (pandanus tectorius) menghasilkan rendemen ekstrak menggunakan pelarut aseton tertinggi pada perbandingan (1:9) dalam tiga perbandingan, yaitu (1:7), (1:9) dan (1:11).

\section{Total Fenolik}

Hasil analisis keragaman menunjukkan bahwa perlakuan perbandingan bahan dengan pelarut aseton berpengaruh sangat nyata $(\mathrm{P}<0,01)$ terhadap total fenol ekstrak Sargassum polycystum. Grafik nilai rata-rata total fenol dari ekstrak Sargassum polycystum dapat dilihat pada Gambar 2.

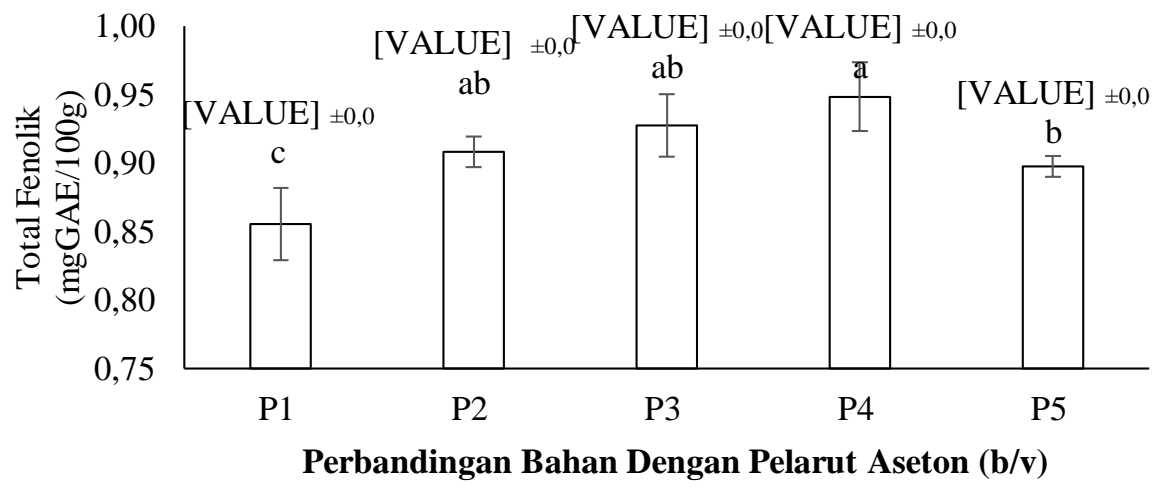

Keterangan:

$\mathrm{P} 1=$ bahan $:$ aseton $=(1: 9)$
$\mathrm{P} 2=$ bahan $:$ aseton $=(1: 11)$
$\mathrm{P} 3=$ bahan $:$ aseton $=(1: 13)$
$\mathrm{P} 4=$ bahan $:$ aseton $=(1: 15)$
$\mathrm{P} 5=$ bahan $:$ aseton $=(1: 17)$

Keterangan: Huruf yang berada di belakang angka menunjukan bawah perbedaan yang nyata $(\mathrm{P}<0,05)$. Data merupakan rata-rata dari tiga ulangan.

Gambar 2. Grafik nilai rata-rata total fenol ekstrak Sargassum polycystum (mgGAE/100g).

Analisis ini menunjukan bahwa pada perlakuan perbandingan bahan dengan pelarut aseton (b/v) P4 (1:15) menghasilkan total fenol ekstrak Sargassum polycystum yang tertinggi, yaitu 0,95 mgGAE/100g. Sedangkan perlakuan P1 (1:9) menghasilkan total fenol ekstrak Sargassum polycystum terendah, yaitu $0,86 \mathrm{mgGAE} / 100 \mathrm{~g}$.

Hal ini menunjukkan bahwa senyawa fenolik dapat terekstrak dan mencapai titik optimumnya. Kemungkinan ini diakibatkan sifat fenol yang larut dalam pelarut organik dan aseton merupakan salah satu pelarut organik yang mampu memecah senyawa organik. Hasil penelitian Nasser (2011) tentang variasi rasio pelarut etanol terhadap kadar oleoresin temulawak menghasilkan senyawa fenol tertinggi pada rasio perbadingan (1:7). Pada perbandingan bahan dengan pelarut (1:15) diduga pelarut yang digunakan telah mencapai titik jenuh, sehingga proses ekstraksi senyawa fenolik yang terdapat pada ekstrak Sargassum polycystum sudah tidak memberi efek kenaikan pada total fenolik. Hal ini didukung penelitian Farida et al. (2015) pada ekstraksi kadar antosianin limbah kulit manggis menghasilkan perbandingan yang optimum yaitu pada rasio 1:20 dibandingkan perlakuan rasio 1:10 dan 1:30. Hal ini diduga terjadi karena pada rasio 1:20 pelarut sudah mencapai titik jenuhnya dan akibatnya pada rasio 1:30 tidak dapat memberi efek kenaikan kadar antosianin ekstrak. 


\section{Intensitas Warna}

\section{a. Tingkat Kecerahan $\left(L^{*}\right)$}

Hasil analisis keragaman menunjukkan bahwa perlakuan perbandingan bahan dengan pelarut aseton berpengaruh sangat nyata $(\mathrm{P}<0,01)$ terhadap tingkat kecerahan $\left(\mathrm{L}^{*}\right)$ ekstrak Sargassum polycystum. Grafik nilai rata-rata tingkat kecerahan (L*) ekstrak Sargassum polycystum dapat dilihat pada Gambar 3.

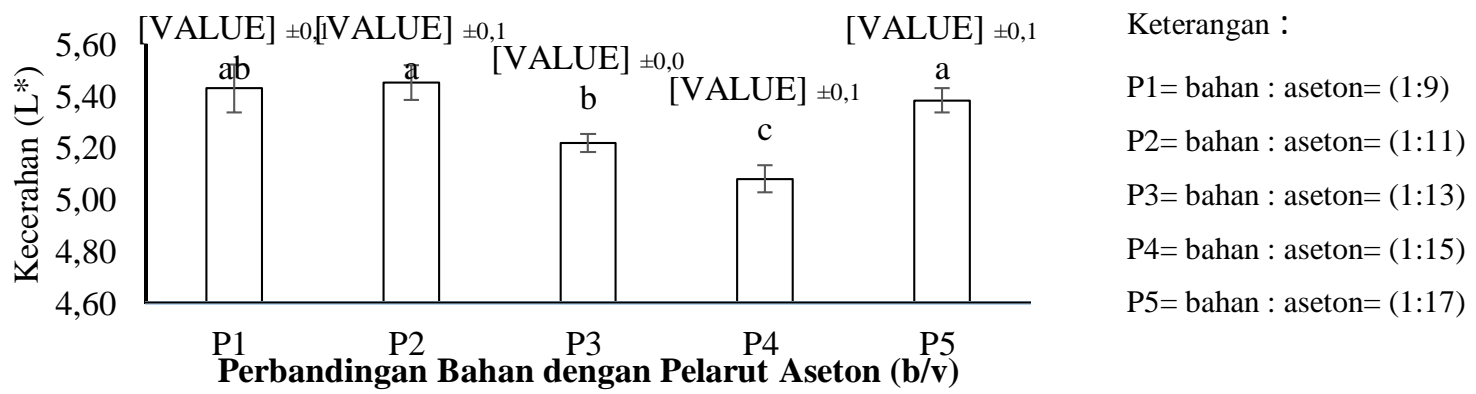

Keterangan: Huruf berbeda yang tertera di setiap grafik batang menunjukkan perbedaan yang sangat nyata $(\mathrm{P}<0,01)$. Data merupakan rata-rata dari tiga ulangan.

Gambar 3. Grafik nilai rata-rata tingkat kecerahan (L*) ekstrak Sargassum polycystum.

Nilai $L^{*}$ menunjukkan tingkat kecerahan warna dari gelap sampai terang dengan kisaran $0-100$. Hasil penelitian menunjukkan perbedaan yang sangat nyata terhadap nilai rata-rata tingkat kecerahan pada perlakuan perbandingan bahan dengan pelarut aseton. Perlakuan perbandingan bahan dengan pelarut aseton (b/v) P4 (1:15) menghasilkan tingkat kecerahan (L*) ekstrak Sargassum polycystum yang rendah yaitu sebesar 5,08. Sedangkan perlakuan perbandingan bahan dengan pelarut aseton (b/v) P5 (1:17) menghasilkan tingkat kecerahan $\left(\mathrm{L}^{*}\right)$ ekstrak Sargassum polycystum yang tinggi yaitu sebesar 5,38 .

Hal ini dikarenakan senyawa bioaktif yang terkandung pada ekstrak Sargassum polycystum dengan perlakuan perbandingan bahan dengan pelarut aseton (b/v) P4 (1:15) terekstrak lebih banyak sehingga tingkat kecerahan yang dihasilkan semakin rendah (gelap). Hasil penelitian Manasika dan Widjanarko (2015) menunjukkan semakin banyak pigmen yang terekstrak menyebabkan warna ekstrak akan semakin gelap dan pekat, sehingga nilai kecerahan menurun.

\section{b. Tingkat Kemerahan (a*)}

Hasil analisis keragaman menunjukkan bahwa perlakuan perbandingan bahan dengan pelarut aseton berpengaruh sangat nyata $(\mathrm{P}<0,01)$ terhadap tingkat kemerahan $\left(\mathrm{a}^{*}\right)$ ekstrak Sargassum polycystum. Grafik nilai rata-rata tingkat kemerahan $\left(\mathrm{a}^{*}\right)$ ekstrak Sargassum polycystum dapat dilihat pada Gambar 4. 


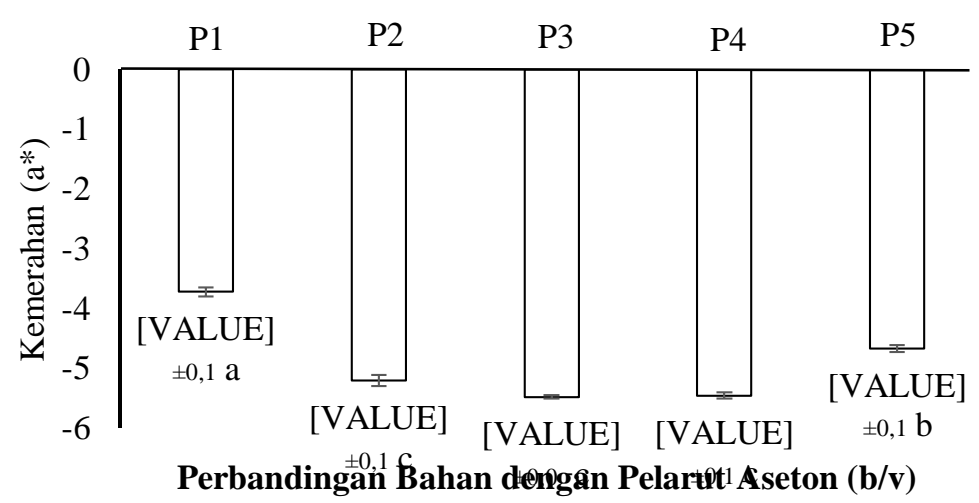

Keterangan:

$\mathrm{P} 1=$ bahan $:$ aseton $=(1: 9)$

$\mathrm{P} 2=$ bahan $:$ aseton $=(1: 11)$

$\mathrm{P} 3=$ bahan $:$ aseton $=(1: 13)$

$\mathrm{P} 4=$ bahan $:$ aseton $=(1: 15)$

P5= bahan : aseton $=(1: 17)$

Keterangan: Huruf berbeda yang tertera di setiap grafik batang menunjukkan perbedaan yang tidak nyata $(\mathrm{P}>0,05)$. Data merupakan ratarata dari tiga kelompok.

Gambar 4. Grafik nilai rata-rata tingkat kemerahan (a*) ekstrak Sargassum polycystum

Nilai a* (tingkat kemerahan) menyatakan tingkat warna hijau sampai merah dengan kisaran nilai -100 sampai +100 . Hasil penelitian menunjukkan perbedaan yang tidak nyata terhadap nilai ratarata tingkat kemerahan $\left(\mathrm{a}^{*}\right)$ pada perlakuan perbandingan bahan dengan pelarut aseton. Sargassum polycystum yang diekstrak menggunakan perlakuan perbandingan bahan dengan pelarut aseton (b/v) P4 (1:15) memiliki nilai rata-rata tingkat kemerahan yang paling rendah yaitu sebesar $-5,46$. Nilai rata-rata tingkat kemerahan tertinggi diperoleh pada perlakuan perbandingan bahan dengan pelarut aseton $(\mathrm{b} / \mathrm{v})$ P1 (1:9) yaitu sebesar -3,72. Hal ini dikarenakan pigmen klorofil pada ekstrak Sargassum polycystum dengan perlakuan perbandingan bahan dengan pelarut aseton (b/v) P4 (1:15) terekstrak lebih banyak sehingga tingkat kemerahan yang dihasilkan semakin rendah. Semakin besar nilai tingkat kemerahan (a*) menunjukkan kecenderungan warna yang semakin merah dan sebaliknya, semakin kecil nilai tingkat kemerahan $\left(\mathrm{a}^{*}\right)$ menunjukkan kecenderungan warna yang semakin hijau. Tingkat kemerahan berkaitan dengan semakin besarnya kelarutan pigmen klorofil, semakin rendah kadar klorofil maka tingkat kemerahan akan semakin tinggi dan sebaliknya semakin tinggi kadar klorofil maka warna yang dihasilkan akan semakin merah (Aryanti et al., 2016).

\section{c. Tingkat Kekuningan (b*)}

Hasil analisis keragaman menunjukkan bahwa perlakuan perbandingan bahan dengan pelarut aseton berpengaruh sangat nyata $(\mathrm{P}<0,01)$ terhadap tingkat kekuningan $\left(\mathrm{b}^{*}\right)$ ekstrak Sargassum polycystum. Grafik nilai rata-rata tingkat kekuningan ( $\left.b^{*}\right)$ ekstrak Sargassum polycystum dapat dilihat pada Gambar 5.

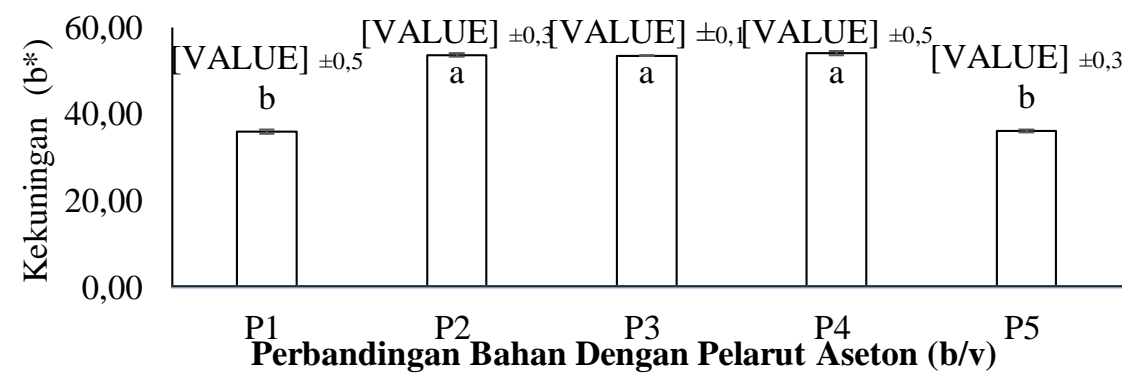

Keterangan:

$\mathrm{P} 1=$ bahan : aseton $=(1: 9)$

$\mathrm{P} 2=$ bahan $:$ aseton $=(1: 11)$

$\mathrm{P} 3=$ bahan $:$ aseton $=(1: 13)$

$\mathrm{P} 4=$ bahan $:$ aseton $=(1: 15)$

$\mathrm{P} 5=$ bahan $:$ aseton $=(1: 17)$

Keterangan: Huruf berbeda yang tertera di setiap grafik batang menunjukkan perbedaan yang tidak nyata $(\mathrm{P}>0,05)$. Data merupakan rata-rata dari tiga kelompok.

Gambar 5. Grafik nilai rata-rata tingkat kekuningan (b*) ekstrak Sargassum polycystum 
Sargassum polycystum yang diekstrak menggunakan perlakuan perbandingan bahan dengan pelarut aseton $(\mathrm{b} / \mathrm{v}) \mathrm{P} 4(1: 15)$ memiliki nilai rata-rata tingkat kekuningan yang paling tinggi yaitu sebesar 54,00. Nilai rata-rata tingkat kekuningan terendah diperoleh pada perlakuan perbandingan bahan dengan pelarut aseton (b/v) P1 (1:9) yaitu sebesar 35,87. Nilai $b^{*}$ (tingkat kekuningan) menyatakan tingkat warna biru sampai kuning kisaran nilai -100 sampai +100 . Hasil penelitian menunjukkan perbedaan yang sangat nyata terhadap nilai rata-rata tingkat kekuningan $\left(b^{*}\right)$ pada perlakuan perbandingan bahan dengan pelarut aseton. Menurut hasil penelitian Zendrato et al. (2014) menyatakan bahwa warna ekstrak pada lamun yang diperoleh dengan proses ekstraksi menggunakan pelarut aseton cenderung berwarna hijau kekuningan. Warna hijau kekuningan menurut Gross (1991) berasal dari komponen klorofil b. Klorofil merupakan senyawa yang sangat sensitif, klorofil akan sangat mudah terdegradasi pada paparan suhu tinggi dan cahaya, sehingga akan mengubah warnanya menjadi kekuningan (Du et al., 2014).

\section{Klorofil}

\section{a. Klorofil a}

Hasil analisis keragaman menunjukkan bahwa perlakuan perbandingan bahan dengan pelarut aseton berpengaruh sangat nyata $(\mathrm{P}<0,01)$ terhadap klorofil a ekstrak Sargassum polycystum. Grafik nilai rata-rata klorofil a ekstrak Sargassum polycystum dapat dilihat pada Gambar 6.

Analisis ini menunjukkan bahwa pada perlakuan perbandingan bahan dengan pelarut aseton (b/v) P4 (1:15) menghasilkan klorofil a ekstrak Sargassum polycystum yang tertinggi, yaitu 279 ppm. Sedangkan Perlakuan P1 (1:9) menghasilkan klorofil a ekstrak Sargassum polycystum terendah, yaitu 143 ppm.
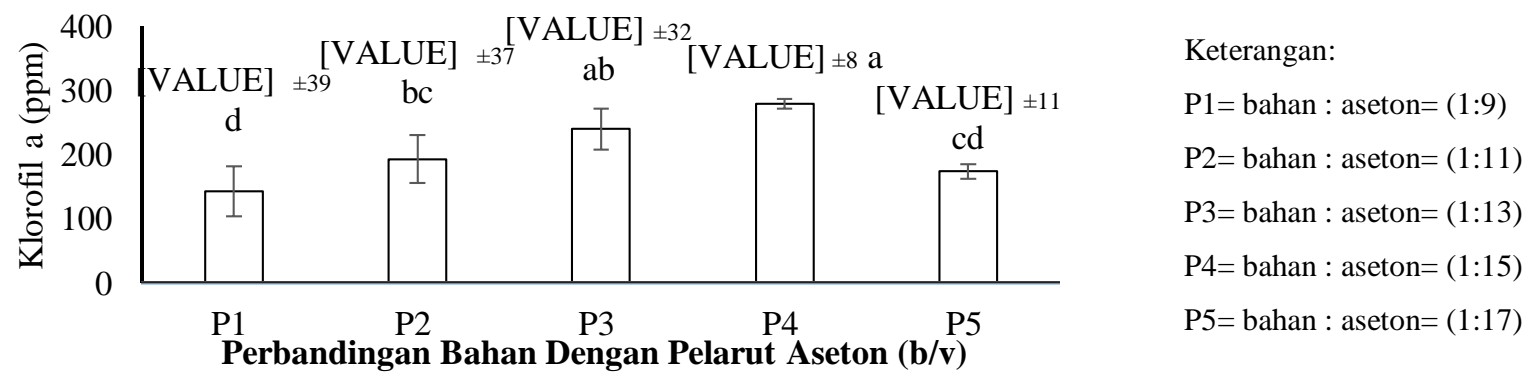

Keterangan: Huruf yang berada di belakang angka menunjukkan bahwa perbedaan yang sangat nyata $(\mathrm{P}<0,01)$. Data merupakan rata-rata dari tiga ulangan.

Gambar 6. Grafik nilai rata-rata klorofil a ekstrak Sargassum polycystum (ppm)

Hal ini menunjukkan bahwa perbandingan bahan dengan pelarut aseton berpengaruh terhadap kadar klorofil a yang dihasilkan. Dari hasil penelitian Farida et al. (2015) pada ekstraksi kadar antosianin limbah kulit manggis menghasilkan perbandingan yang optimum yaitu pada rasio 1:20 dibandingkan perlakuan rasio 1:10 dan 1:30. Hal ini diduga terjadi karena pada rasio 1:20 pelarut sudah mencapai titik jenuhnya dan akibatnya pada rasio 1:30 tidak dapat memberi efek kenaikan kadar antosianin ekstrak. Hasil ini juga didukung oleh penelitian dari Prasetyo et al. (2012) tentang Pengaruh Rasio Massa Daun Suji / Pelarut, Temperatur dan Jenis Pelarut Pada Ekstraksi Klorofil daun Suji yang 
menyatakan bahwa pelarut aseton lebih cenderung melarutkan komponen klorofil a yang berwarna kebiruan.

\section{b. Klorofil b}

Hasil analisis keragaman menunjukkan bahwa perlakuan perbandingan bahan dengan pelarut aseton berpengaruh nyata $(\mathrm{P}<0,05)$ terhadap klorofil b ekstrak Sargassum Polycystum. Grafik nilai ratarata klorofil b ekstrak Sargassum polycystum dapat dilihat pada Gambar 7.
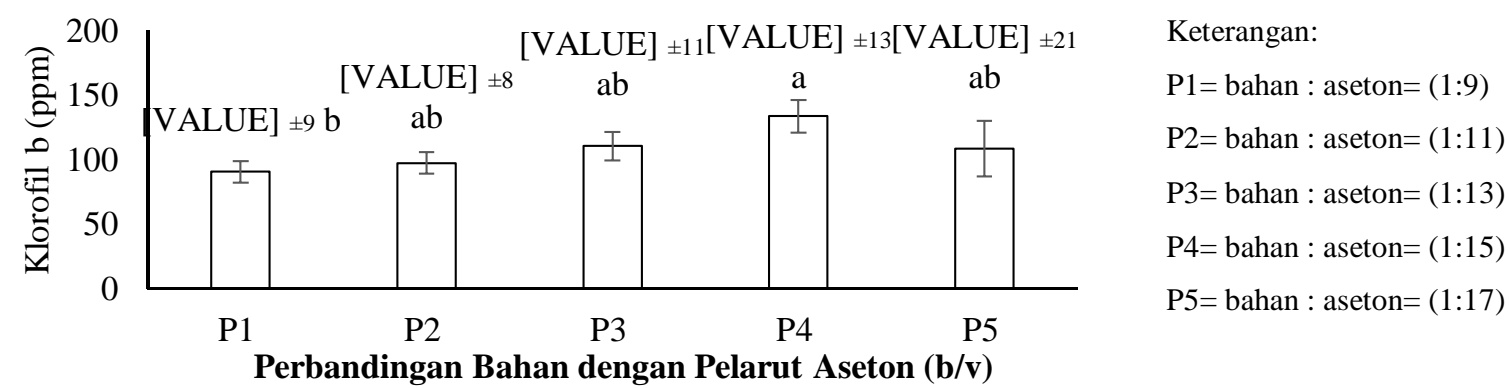

Perbandingan Bahan dengan Pelarut Aseton (b/v)

Keterangan: Huruf di belakang angka menunjukkan bahwa perbedaan yang nyata $(\mathrm{P}<0,05)$. Data merupakan ratarata dari tiga ulangan.

Gambar 7. Grafik nilai rata-rata klorofil b ekstrak Sargassum polycystum (ppm)

Analisis ini menunjukkan bahwa pada perlakuan perbandingan bahan dengan pelarut aseton (b/v) P4 (1:15) menghasilkan klorofil b ektrak Sargassum polycystum yang tertinggi, yaitu 134 ppm. Sedangkan perlakuan P1 (1:9) menghasilkan klorofil b dari ekstrak Sargassum polycystum terendah, yaitu $91 \mathrm{ppm}$.

Hal ini menunjukkan bahwa perbandingan bahan dengan pelarut dengan pelarut aseton berpengaruh terhadap kadar klorofil b yang dihasilkan. Dari penelitian Farida et al. (2015) pada ekstraksi kadar antosianin limbah kulit manggis menghasilkan perbandingan yang optimum yaitu pada rasio 1:20 dibandingkan perlakuan rasio 1:10 dan 1:30. Hal ini diduga terjadi karena pada rasio 1:20 pelarut sudah mencapai titik jenuhnya dan akibatnya pada rasio 1:30 tidak dapat memberi efek kenaikan kadar antosianin ekstrak. Hasil ini juga didukung oleh penelitian dari Prasetyo et al. (2012) tentang Pengaruh Rasio Massa Daun Suji / Pelarut, Temperatur dan Jenis Pelarut Pada Ekstraksi Klorofil daun Suji yang menyatakan bahwa pelarut aseton lebih cenderung melarutkan komponen klorofil a, oleh karena itu warna hijau yang dihasilkan lebih kebiruan.

\section{c. Total Klorofil}

Hasil analisis keragaman menunjukkan bahwa perlakuan perbandingan bahan dengan pelarut aseton berpengaruh sangat nyata $(\mathrm{P}<0,01)$ terhadap total klorofil ekstrak Sargassum polycystum. Grafik nilai rata-rata total klorofil ekstrak Sargassum polycycstum dapat dilihat pada gambar 8 . 


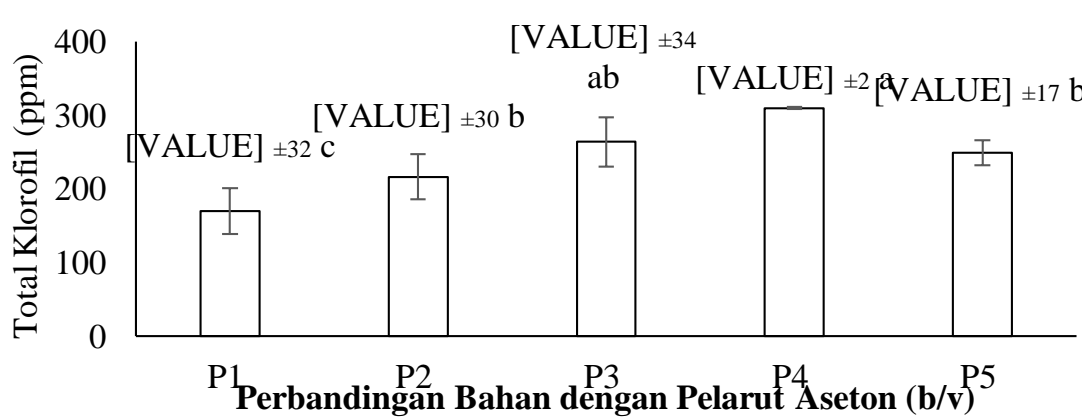

Keterangan:

$\mathrm{P} 1=$ bahan $:$ aseton $=(1: 9)$

$\mathrm{P} 2=$ bahan : aseton $=(1: 11)$

$\mathrm{P} 3=$ bahan $:$ aseton $=(1: 13)$

$\mathrm{P} 4=$ bahan $:$ aseton $=(1: 15)$

$\mathrm{P} 5=$ bahan $:$ aseton $=(1: 17)$

Keterangan: Huruf di belakang angka menunjukkan bahwa perbedaan yang sangat nyata $(\mathrm{P}<0,01)$. Data merupakan rata-rata dari tiga ulangan.

Gambar 8. Grafik nilai rata-rata total klorofil ekstrak Sargassum Polycystum.

Analisis ini menunjukkan bahwa pada perlakuan perbandingan bahan dengan pelarut aseton (b/v) P4 (1:15) menghasilkan total klorofil ekstrak Sargassum polycystum yang tertinggi, yaitu 310 ppm. Sedangkan perlakuan P1 (1:9) menghasilkan total klorofil ekstrak Sargassum polycystum terendah, yaitu $170 \mathrm{ppm}$.

Hal ini menunjukkan bahwa perbandingan bahan dengan pelarut aseton berpengaruh terhadap kadar total klorofil yang dihasilkan. Pada perbandingan bahan dengan pelarut aseton 1:15, pelarut sudah mencapai titik jenuhnya sehingga kadar klorofil yang dapat terekstrak dari bahan semakin sedikit. Hasil ini didukung oleh penelitian dari Kwartiningsih et al.(2016) yang meneliti tentang kadar antosianin dari kulit buah naga, pada variasi perbandingan pelarut dan bahan menghasilkan kadar antosianin terbesar pada perbandingan 1:6 dibandingkan dengan variasi perbandingan 1:2, 1:4, 1:8 dan 1:10. Diduga pada variasi perbandingan 1:6 pelarut sudah mencapai titik jenuhnya sehingga zat pigmen yang dihasilkan semakin sedikit.

\section{KESIMPULAN DAN SARAN}

\section{Kesimpulan}

1. Perbandingan bahan dengan pelarut berpengaruh sangat nyata terhadap parameter rendemen, intensitas warna $\left(\mathrm{L}^{*}, \mathrm{a}^{*}, \mathrm{~b}^{*}\right)$, total fenolik, kadar klorofil a dan total klorofil ekstrak Sargassum polycystum. Sedangkan pada parameter kadar klorofil b menunjukkan bahwa perlakuan yang berpengaruh nyata $(\mathrm{P}<0,05)$.

2. Perbandingan bahan dengan pelarut aseton (1:15) b/v merupakan perlakuan terbaik dengan hasil rendemen 2,40\%, intensitas warna $\left(\mathrm{L}^{*}\right)$ 5,08, (a*) -5,46, (b*) 54,00, total fenolik 0,95 (mgGAE/100g), klorofil a 279 (ppm), klorofil b 134 (ppm), dan total klorofil 310 (ppm).

\section{Saran}

Berdasarkan hasil penelitian, disarankan menggunakan perbandingan bahan dengan pelarut yang lebih optimum pada perbandingan (1:15) untuk menghasilkan ekstrak Sargassum polycystum terbaik. 


\section{DAFTAR PUSTAKA}

Antari, N.M.R.O., N.M. Wartini dan S. Mulyani. 2015. Pengaruh ukuran partikel dan lama ekstraksi terhadap karakteristik ekstrak warna alami buah pandan (Pandanus tectorius). Jurnal Rekayasa dan Manajemen Agroindustri. 3(4): 1-11.

Aryanti, N., A. Nafiunisa, dan F.M. Wilis. 2016. Ekstraksi dan karakterisasi klorofil dari daun suji (Pleomele angustifolia) sebagai pewarna pangan alami. Jurnal Aplikasi Teknologi Pangan. 5(4): 129-135.

Atmadja, W.S., Kadi, A., Sulistijo dan Rachmaniar. 1996. Pengenalan Jenis-Jenis Rumput Laut Indonesia. Jakarta: Pusat Penelitian dan Pengembangan Oseanologi Lembaga Ilmu Pengetahuan Indonesia, Jakarta.

Baihakki., Feliatra, dan T. Wikanta. 2014. Extraction of polyphenol From Sargassum sp. And Its Entrapment In The Nanochitosan. Fakultas Kelautan dan Perikanan. Universitas Riau. 1 (1): 115.

Dewi, N.N.D.T., L. P. Wrasiati, dan G. P. Ganda Putra. 2016. Pengaruh konsentrasi pelarut etanol dan suhu maserasi terhadap rendemen dan kadar klorofil produk enkapsulasi selada laut (Ulva lactuca L). Jurnal Rekayasa dan Manajemen Agroindustri, 4 (3): 1-4.

Diantika, F., Sutan, S.M., Yulianingsih, R. 2014. Effect of Long Extraction and Concentration and Concentration of Ethanol Solvent Extraction Antioxidant Cocoa Beans (Theobroma cacao L.). Jurnal Teknologi Pertanian. Jurusan Keteknikan Pertanian, Fakultas Teknologi Pertanian, Universitas Brawijaya Malang. 15 (3).

Du, L., X. Yang, J. Song, Z. Ma, Z. Zhang, and X. Pang. 2014. Characterization of the stage dependency of high temperature on green ripening reveals a distinct chlorophyll degradation regulation in banana fruit. Journal of Scientia Horticulturae. 180: 139-146.

Eriningsih, R., Rini Marlina,Theresia Mutia, Arif Wibi Sana, Anna Titis. 2014. Eksplorasi Kandungan Pigmen Dan Alginat Dari Rumput Laut Coklat Untuk Proses Pewarnaan Kain Sutera. Balai Besar Tekstil. Bandung.

Gross, J. 1991. Pigments in Vegetables, Chlorophylls and Carotenoids. Van Nostrand Reinhold, New York.

Kwartiningsih, E., A. Prastika, dan D. L. Triana. 2016. Ekstraksi dan Uji Stabilitas Antosianin dari Kulit Buah Naga Super Merah (Hylocereus costaricensis). Fakultas Teknik. Universitas Sebelas Maret, Surakarta.

Maeda, H., Hosokawa, M., Sashima, T., Funayama, K. dan Miyashita, K. 2005. Fukoxanthin from Edible Seaweed, Undaria pinnatifida, Shows Antiobesity Effect Through UCP1 Expression in White Adipose Tissues. Biochemical and biophysical research communication3. 32: 392-397.

Manasika, A., dan S.B. Widjanarko. 2015. Ekstraksi pigmen karotenoid labu kabocha menggunakan metode ultrasonik (kajian rasio bahan: pelarut dan lama ekstraksi). Jurnal Pangan dan Agroindustri. 3 (3):928-938.

Nara, E. K., Akira. A. dan Akihiko, N. 2005. Neoxantin and Fucoxanthin Induce Apoptasis in PC-3 Human Prostate Cancer Cells. Cancer Letters, 220(1): 75-84

Nasser, H. 2011. Pengaruh Variasi Rasio Pelarut Dan Waktu Perendaman Terhadap Kadar Kurkuminoid, Total Fenol, Dan Aktivitas Antioksidan Pada Oleoresin Lumpang Temulawak (Curcuma xanthorriza Roxb.) Dengan Pengeringan Cabinet Dryer. Dipublikasikan. Skripsi S1.Fakultas Pertanian. Universitas Sebelas Maret, Surakarta.

Nollet, LML. 2004. Handbook of Food Analysis. Physical Characterzati-ion and Nutrient Analysis. Marcel Dekker. Inc. 1(2). New York. 
Nomura, T., Kikuchi M., Kubodera A. dan Kawakami, Y. 1997. Proton-donative Antioxidant Activity of Fucoxanthin with 1,1-diphenyl-2-picrylhydrazyl (DPPH). Biochem Mol Biol Int. 42(2): 36170.

Panovska, T. K., Kulevanova, S. dan Stenova, M. 2005. In Vitro Antioxidant of Some Teucrium Spesies (Lamiaceae). Journal Acta pharmachology, 55(2).27-214.

Prasetyo, S., Sanjaya, H. dan Yohanes, YN. 2012. Pengaruh Rasio Massa Daun Suji / Pelarut, Temperatur Dan Jenis Pelarut Pada Ekstraksi Klorofil Daun Suji Secara Batch Dengan Pengontakan Dispersi. Lembaga Penelitian dan Pengabdian kepada Masyarakat. Universitas Katolik Parhayangan. 3 (2): 45-55.

Sakanaka, S., Y.Tachibana, and O.Yuki. 2005. Preparationand antioxidant properties of extracts of Japanese persimo leaf tea (kakinocha-cha). Food chemistry 89. 569-575

Sudarmadji, S., B. Haryono, dan Suhardi. 1989. Prosedur Analisa untuk Bahan Makanan dan Pertanian. Penerbit Liberty : Yogyakarta Suparmi, dan S. Achmad. 2009. Mengenal potensi rumput laut: Kajian pemanfaatan sumber daya rumput laut dari aspek industri dan kesehatan. 44(118): 95116.

Weaver, C. 1996. The Food Chemistry Laboratory. CRC Press, Boca Raton, New York, london, Tokyo.

Wignore, Ann. 1985. The Wheatgrass Book. Avery Books.

Yudharini, G. A. K. F., A. A. P. A. S. Wiranatha dan N. M. Wartini. 2016. Pengaruh Perbandingan Bahan Dengan Pelarut Dan Lama Ekstraksi Terhadap Rendemen Dan Karakteristik Ekstrak Pewarna Dari Buah Pandan (Pandanus tectorius). Jurnal Rekayasa dan Manajemen Agroindustri. 4 (3): 36-46.

Zendrato, I. A., F. Swatawati., dan Romadhon. 2014. Ekstraksi klorofil dan karotenoid dengan konsentrasi pelarut yang berbeda pada lamun (Enhalusacoroides) di Perairan Laut Jawa. Jurnal Pengolahan dan Bioteknologi Hasil Perikanan. 3 (1): 30-39. 